PDFlib PLOP: PDF Linearization, Optimization, Protection

Page inserted by evaluation version www.pdflib.com - sales@pdflib.com 


\title{
Television Violence Viewing and Aggression in Females
}

\author{
JESSICA F. MOISE AND L. ROWELL HUESMANN ${ }^{a}$ \\ The Institute for Social Research \\ The University of Michigan \\ P.O. Box 1248 \\ Ann Arbor, Michigan 48109-1248
}

\begin{abstract}
Although the literature on the long-term effects of television violence viewing on aggression has demonstrated unambiguously that for boys early exposure to media violence increases the risk for later aggressive behavior, the results for girls have been less clear. In the 1960 s, laboratory studies showed short-term effects for girls, but little evidence could be found for long-term effects on girls or young women in field studies. ${ }^{1}$ More recently, however, one three-year field study, which was started in the 1970s, did find a relationship between violence viewing in the first year of the study and aggression two years later for girls, ages 6 to $11 .^{2}$ It may be that recent increases in violence in the media and in societal acceptance of aggression by girls are changing the magnitude of the effect for females. The major purpose of the current study is to examine the long-term effects of early violence viewing on later aggressive behavior on girls during the 1980 s and 1990s.
\end{abstract}

\section{METHOD}

The current report examines these relationships in girls with data from a 15year follow-up of 384 girls who were originally assessed in 1977 (when they were in either first or third grade). Two hundred and eleven of these girls were reinterviewed 14-16 years later. The procedure for the child interviews has been described in detail in Huesmann and Eron. ${ }^{2}$ For the follow-up study, subjects either came into the University of Illinois, Chicago and completed an interview using a computer $(\mathrm{N}=154)$, or the subject completed a combination phone and mail version of the interview $(\mathrm{N}=57)$.

In the initial study, children were asked about their favorite TV programs (which were then coded for violence level) and how often they watched them, about how much they thought they were "like" aggressive TV characters, and about how much they fantasized about aggression. Children's aggressive behavior was measured using the peer-nominated aggression index. For a complete description of these measures, see Huesmann and Eron. ${ }^{2}$ In the follow-up study, we remeasured each of these variables using procedures very similar to those described for the early waves, except the questions were adapted to an adult sample. To measure adult aggression, we asked them to report their frequency of engaging in indirect aggression and mild physical aggression, ${ }^{3}$ self-rated aggressive

${ }^{a}$ Tel: (313) 763-4844; fax: (313) 763-1202; e-mail: jmoise@umich.edu. 


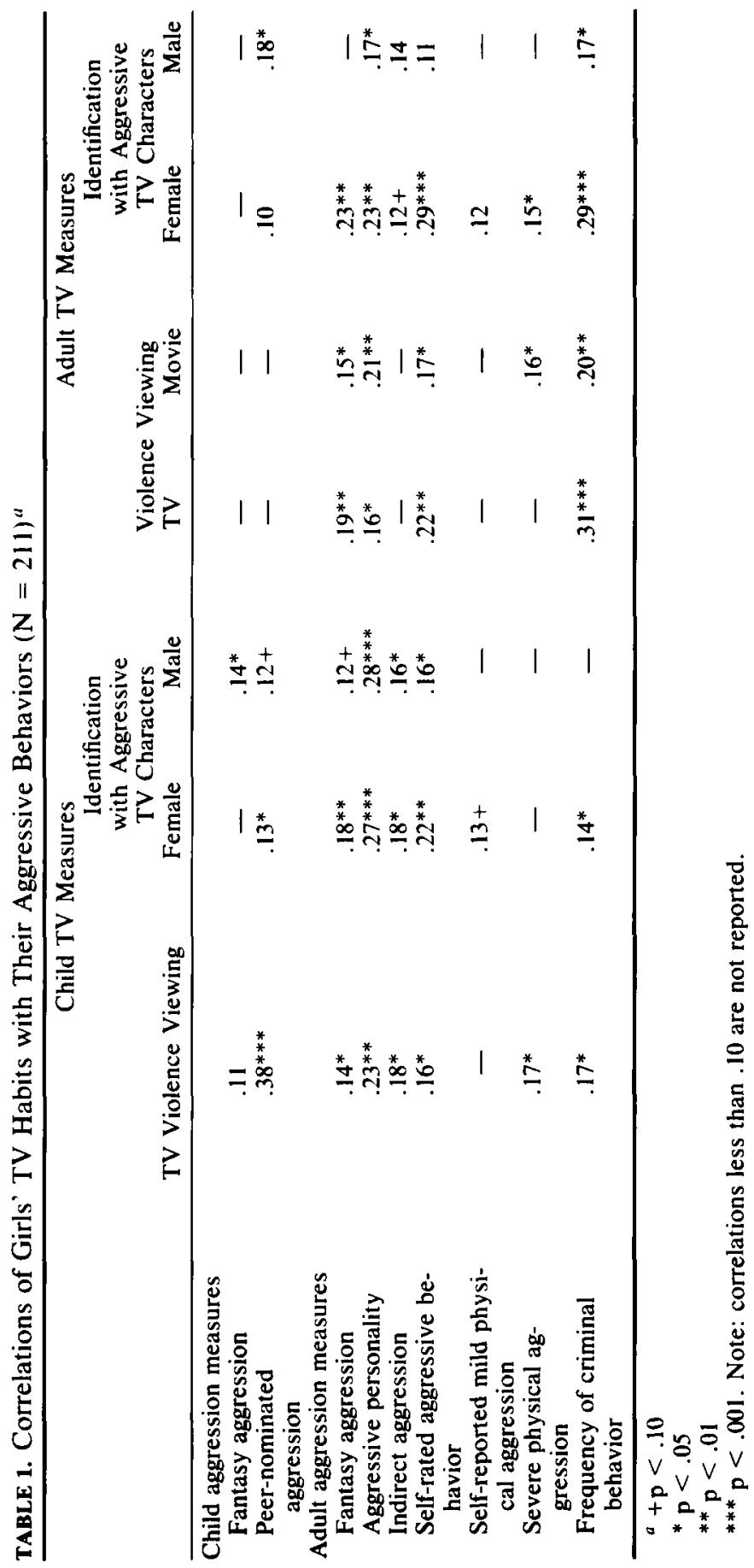



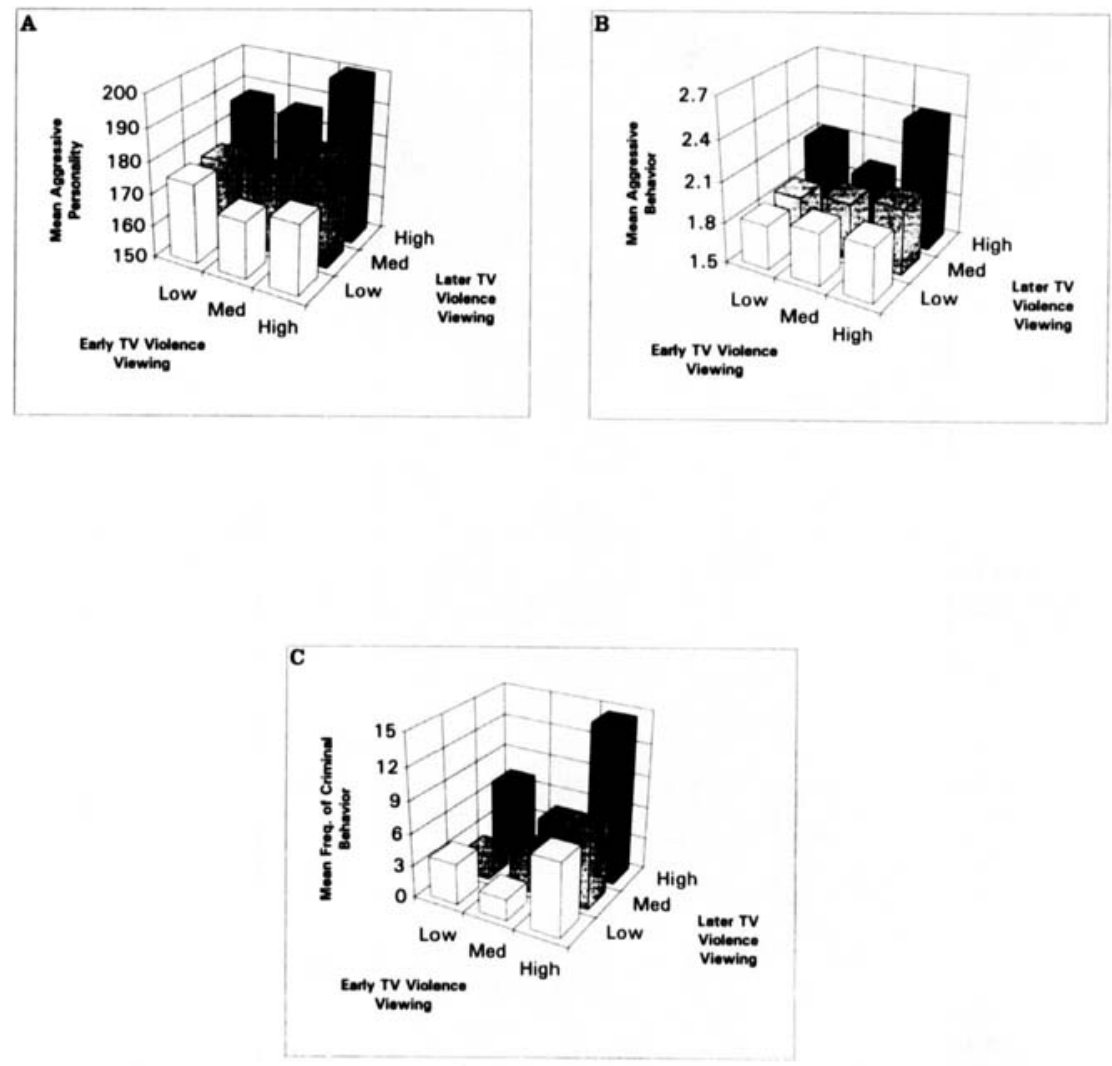

FIGURE 1. A. Aggressive personality (MMPI F $+4+9$ ) as a function of early and later TV violence viewing. $F(2,185)=6.50, p<.01$ for early TV violence viewing; $F(2,185)=$ $2.99, p=.05$ for later TV violence viewing. B. Frequency of self-rated aggressive behavior as a function of early and later TV violence viewing. $F(2,193)=4.60, p<.05$ for early TV violence viewing; $F(2,193)=2.93, p<.10$ for later $T V$ violence viewing. C. Frequency of criminal behavior as a function of early and later TV violence viewing. $F(2,193)=4.15$, $p<.05$ for early TV violence viewing; $F(2,193)=8.81, p<.001$ for later TV violence viewing.

behavior, ${ }^{2}$ severe physical aggression, ${ }^{2}$ and criminal behavior. ${ }^{4}$ In addition, subjects were given the MMPI, and the $F, 4$, and 9 scales were combined as a measure of aggressive personality.

\section{RESULTS}

As TABLE 1 reveals, for females, watching violent media and identification with aggressive TV characters (especially female characters) are significantly correlated with aggression and with fantasy about aggression, both in childhood and in adulthood. In addition, childhood television variables are significantly correlated 
with many adult aggression variables, but the reverse does not hold true. That is, childhood aggression variables for the most part are not correlated with adult TV violence viewing. Although the correlations are not large, many of them are significant, indicating that early TV violence viewing and identification with aggressive TV characters are related to later aggression and fantasizing about aggression.

We also examined the differences in mean scores on these measures for those who were high TV violence viewers both as children and as adults compared to those who were low or medium TV violence viewers. The results, shown in FIGURE 1, indicate that both early and later TV violence viewing independently have a significant main effect on aggression.

\section{DISCUSSION}

The results of this sudy indicate that there now does exist a relationship between television violence viewing and aggression for females-in childhood, in adulthood, and across time. Although this preliminary analysis does not test causality, the results in conjunction with the large body of literature supporting a causal model for boys suggest that it is plausible to conclude that viewing television violence can lead to the development of aggression for girls as well as for boys. Moreover, the results suggest that this relationship is exacerbated by identification with aggressive television characters and fantasizing about aggression.

\section{REFERENCES}

1. Eron, L. D., L. R. Huesmann, M. M. Lefkowitz \& O. Walder. 1972. Does television violence cause aggression? Am. Psychol. 27: 253-263.

2. HuesmanN, L. R. \& L. D. Eron. 1986. Television and the Aggression Child: A CrossNational Comparison. Erlbaum. Hillsdale, NJ.

3. Bjorkovist, K., K. Oysterman \& A. Kaukiainen. 1992. The development of direct and indirect aggressive strategies in males and females. In Of Mice and Women: Aspects of Female Aggression. K. Bjorkqvist \& P. Niemela, Eds. Academic Press. New York.

4. El.liot, D. S., F. W. Dunford \& D. H. Huizinga. 1987. The identification and prediction of career offenders utilizing self-reported and official data. In Prevention of Delinquent Behavior. J. D. Burchard \& S. N. Burchard, Eds. Sage. Newbury Park.

5. HuesmanN, L. R., M. M. Lefkowitz \& L. D. ERon. 1978. Sum of MMPI Scales F, 4, 9 as a measure of aggression. J. Consult. Clin. Psychol. 46: 1071-1078. 